\title{
CONFLITOS E CONTRADIÇÕES NAS RAIIZES DOS MOVIMENTOS SOCIAIS RURAIS BRASILEIROS ${ }^{1}$
}

\author{
Emerson Dias \\ Mestrando em Ciências Sociais / UEL \\ E-mail: emersondias1@hotmail.com
}

\section{Resumo}

A história dos movimentos sociais do campo no Brasil é repleta de ações e reações, de iniciativas organizadas e instintivas, fluxo e refluxo. Este artigo tem como objetivo mapear, até o presente momento, alguns "caminhos históricos" que nortearam os primeiros homens - fossem eles índios, negros, imigrantes ou proletários brancos - a se mobilizarem contra a opressão do capital, do latifúndio e de um Estado que sempre atuou como tutor de uma realidade agrária engessada. A mesma realidade cujas engrenagens enferrujadas vêm sendo movidas à força nas últimas décadas, arrastadas por mobilizações comunitárias que representam um caminho alternativo para a democratização da terra.

Palavras-chave: movimentos sociais do campo; história do Brasil rural; MST.

\footnotetext{
${ }^{1}$ Este artigo é uma adaptação do trabalho "Raízes históricas e sociológicas do movimento social rural brasileiro" apresentado ao final da disciplina Teoria Social II, ministrada pela Prof ${ }^{a} \mathrm{Dr}^{\mathrm{a}}$ Maria José de Rezende, do Curso de Mestrado em Ciências Sociais da UEL, em 2002.
} 
O padre Nóbrega definiu bem o fato, na célebre carta ao rei (1549) em que, pintando com ingênuo realismo a dissociação dos costumes, declara estar o interior do país cheio de filhos de cristãos, multiplicando-se segundo os hábitos gentílicos. Achava conveniente que the enviassem órfãs, ou mesmo mulheres que fossem erradas, que todas achariam maridos, por ser a terra larga e grossa (CUNHA, 1957, p.80).

curiosa citação acima é de Euclides da Cunha que, logo nas primeiras páginas da mítica e (hoje) centenária obra Os Sertões, esboçava as impressões preliminares de uma colonização deturpada, aliciadora e principalmente usurpadora por parte da Coroa portuguesa. Mas a imagem ingênua registrada no início do século XVI - pouco depois da esquadra de Pedro Álvares Cabral aportar em terras brasileiras - sobre uma terra vasta, repleta de libertinagem e de "maridos cristãos" inferiores à raça ibérica, logo seria quebrada pela reação dos nativos. Nas primeiras décadas de colonização, portugueses desbravadores enfrentaram o primeiro movimento popular do país. Chamado de Santidade, o agrupamento era formado por diversos pajés tupinambá que, redistribuídos em novos grupos (ou em outras Santidades), percorriam as aldeias pregando a "vinda de um novo tempo e o retorno à Idade do Ouro", ideal semelhante às mitologias européias:

É a ida a um espaço sagrado, à longínqua 'terra da imortalidade', para onde iam os espíritos dos guerreiros mortos, das esposas dos bravos e dos que lidavam com os ancestrais, desde que ultrapassassem os perigos que obstavam a marcha para o paraíso (VAINFAS, 1992, p.76).

Tal qual o referencial nórdico viking (onde os bravos mortos em combate eram levados ao Valhala pelas valquírias, amazonas celestiais) ou do Olimpo grego (terra dos deuses sonhada pelos mortais), as Santidades resgatavam a busca dos índios pelo paraíso, reforçando a resistência da raça à dominação lusitana e, especialmente, ao crescimento da conversão dos nativos à fé cristã, trazida pela sociedade colonial. Com a ampliação descomunal dos vilarejos portugueses, a escravidão dos seus e a pregação quase que doentia da 
Igreja em terras brasileiras, a pajelança tentava disseminar o ideal da "Terra da Imortalidade" dia após dia.

O prêmio almejado pelos guerreiros - seja a ida ao "Paraíso na Terra" dos Tupinambá ou à "Terra sem Males" dos Tupi ${ }^{2}$ - ampliava o ânimo dos valentes durante confrontos com os colonos e até mesmo contra índios que se aliaram aos inimigos. Aliás, para os líderes messiânicos aborígenes, o paraíso não era tão distante quanto o imaginado pelos brancos. Estava incrustado no fundo da selva tropical, possivelmente em algum vale perdido. E esta terra sagrada com certeza não estaria mais banhada pelo mar, já que a invasão portuguesa dominou e maculou toda a orla conhecida do país. A busca pela Terra da Imortalidade seguiu para o interior do Brasil colônia.

O Paraíso mítico é, portanto, em essência um mundo em que se há de concretizar um ideal de vida tal qual o Guarani desejaria realizá-lo nesta terra, em conformidade com o seu conceito de existência humana, culturalmente definido. O que não impede, é evidente, que se tenda a expurgar a vida paradisíaca de quantas contrariedades de ordinário tornam penosa a que se leva cá em baixo. Do contrário, não seria Paraíso (SCHADEN, 1969, p.247).

A conversão dos indígenas para a fé cristã, além de se tornar um dos objetivos primordiais da coroa portuguesa (para conquistar as "boas graças do Deus Pai misericordioso"), também se tornaria uma das armas de combate para ampliar a dominação dos europeus sobre o Oeste da América do Sul, a partir das areias banhadas pelo Oceano Atlântico.

Para a Igreja católica, o movimento das Santidades era uma

\footnotetext{
${ }^{2}$ Vale ressaltar que outras manifestações messiânicas indígenas podem ser identificadas na história do Brasil colonial. Vide pesquisas antropológicas de Egon Schaden: "[...]Verifica-se que em grande maioria das manifestações messiânicas entre aborígenes brasileiros pertence a tribos do grupo Tupi-guarani; além dos Guarani, caberia então mencionar os antigos Tupinambá. Especial importância tiveram ainda fenômenos similares em populações indígenas Aruák e Tukáno da área do Rio Negro e, por fim, entre os Tukúna do Solimões" (SCHADEN, 1969, p.246).
} 
ameaça concreta ao seu projeto de catequese e ao projeto colonizador. O clero via esse movimento como de origem herética e obra de feitiçaria. O combate sem trégua aos pajés que pregavam as santidades passou a ser defendido abertamente pela Igreja, que utilizou o Tribunal do Santo Ofício como instrumento de investigação e punição adequado para garantir a homogeneidade religiosa na colônia (AQUINO et al., 2000, p.26)

Conflitos registrados entre tribos e colonizadores retardaram o mapeamento e a ocupação das terras brasileiras durante os séculos seguintes. Basta citar a Guerrilha Mura que impediu o avanço português para o interior da Amazônia por um século inteiro (1689-1789), dominada somente após o aldeamento dos índios por membros da Ordem dos Carmelitas (AQUINO et al., 2000, p.26). Quando não era por meio da doutrinação e do aliciamento, os entraves eram resolvidos à força, como ocorreu na Guerra dos Manau (1723 - 1728), quando o grupo liderado pelo tupi Ajuricaba barrou a passagem dos colonizadores ao outro lado do Rio Negro (Alto Amazonas) durante quatro anos. A solução, como não poderia deixar de ser, foi simples e direta: bombardeios navais sobre as aldeias ribeirinhas, vitimando centenas de pessoas. Mesmo sobre forte pressão e desvantagem descomunal diante do inimigo "civilizado", percebe-se na resistência do índio a insistência pela manutenção dos referenciais absorvidos de geração em geração. E neles estão inseridos a integridade da raça e os direitos "concedidos pelos deuses", entre os quais a liberdade de viver sobre a terra onde pisaram seus antepassados.

A influência ativa da organização social nas relações de povos em contato (transitório, intermitente ou permanente) revelase, principalmente, sob dois aspectos: a) estaticamente, pela capacidade de manter, em situações sociais mais complexas e instáveis, a integridade e a autonomia da ordem social estabelecida; b) dinamicamente, pela capacidade de submeter as situações sociais emergentes ao controle social eficiente, mediante a reintegração estrutural e funcional do padrão de equilíbrio inerente à ordem social estabelecida (FERNANDES, 1960, p.80). 
Percebe-se que os anseios dos índios desde 1.500 não eram tão místicos quanto se observava à primeira vista. Longe de buscarem a salvação da alma ou o perdão dos pecados tão pregados pelos cristãos, os nativos queriam simplesmente viver em um local onde pudessem encontrar paz, criar seus filhos, construir suas ocas e garantir terra para plantar, caçar e pescar.

É preciso repensar o que aprendemos na escola sobre a origem dos territórios brasileiros. Não foi somente a busca pela soberania nacional e a demarcação das fronteiras que nortearam tais conflitos já nas décadas iniciais do Brasil Colônia. Assim como o desenvolvimento dos seus primeiros latifúndios ${ }^{3}$, a expropriação violenta das terras foi igualmente iniciada nos primórdios da dominação portuguesa, onde imigrantes, escravos e pequenos produtores eram excluídos do siste-

\footnotetext{
${ }^{3}$ Apesar de aqui nos atermos às mobilização sociais rurais, lembramos que há vários estudos clássicos sobre a origem do latifúndio no Brasil (Vide Quatro Séculos de Latifúndio, de Alberto Guimarães; A Formação Econômica do Brasil, de Celso Furtado; A Formação Histórica do Brasil, de Nelson Wernek Sodré; História Econômica do Brasil, de Caio Prado Júnior; entre outros) onde apontam raízes históricas diversas. Entre elas, estão a do Período Açucareiro (auge da difusão de engenhos pelo País, entre os séculos XVI e XVII), a interiorização da pecuária (a partir do decreto da Coroa Portuguesa de 1688 , que proibia a criação de gado dentro de uma área de dez léguas próxima ao litoral) ou ainda a expansão da cafeicultura no início do século XIX. Para alguns autores, o latifúndio teve origem já na metade do século XVI, com a instituição das sesmarias, lotes de terras repassados pelos donatários das Capitanias Hereditárias: "Ao contrário da capitania, onde o donatário não era proprietário, apenas usufruía os benefícios que dela pudessem ser extraídos, a sesmaria era propriedade de quem a recebia. Aliás, as sesmarias dariam origem à formação de latifúndios tão marcantes na história brasileira" (AQUINO,2000, p.159). Apesar dessa tese ser questionada por vários autores, preferimos ressaltar que qualquer exemplo citado antes (açúcar, gado, etc) teve suas raizes no usufruto das sesmarias. Merece também destaque a Lei das Terras de 1850 , que passou a impedir legalmente qualquer ocupação ou doação de áreas, instituindo-se aí a terra como mercadoria. Sobre as discordâncias relacionadas aos latifúndios, o mesmo AQUINO (2000, p. 552) alerta: "Devemos, portanto, considerar nesse contexto que [além das Sesmarias e Lei de Terras] outros fatores contribuíram para as alterações da estrutura agrária do país: o problema da mão-de-obra; as condições de escoamento da produção; o afluxo de capitais para a lavoura e as questões políticas que tal situação econômica criou".
} 
ma agrário. A determinação dos nativos, reprimida com igual intensidade pelos colonizadores, marcaram o início dos conflitos pelo direito a um pedaço de chão para garantir uma vida digna às famílias legitimamente brasileiras.

Euclides da Cunha (1957) já destacava a preocupação (ou desespero) do sertanejo em garantir tal espaço. Tanto que o pesquisador identifica em sua obra o distanciamento destes homens do litoral - repleto de brancos, negros e "mulatos desequilibrados" - perdidos em uma região dominada pela tal civilização. A busca pelo interior inconscientemente resgatava as Santidades - a vereda da Terra sem Males - e que possivelmente teria sido encerrada em Canudos, reduto de um dos mais importantes grupos de resistência à repressão republicana da história. O movimento, curiosamente tachado como "monarquista", tornou-se um marco como a primeira grande inversão de referências: monarquia $\mathrm{x}$ movimento republicano, seguida por república $\mathrm{x}$ sebastianismo.

Foi no aprofundamento em direção às terras interioranas que 0 autor identificou uma possível resposta que sintetizasse a muralha étnica que resistiu aos ataques incessantes do Exército brasileiro entre 1896 e 1897.

\begin{abstract}
Neste caso a raça forte não destrói uma raça pelas armas: esmaga-a pela civilização. Ora, os nossos rudes patrícios do norte forraram-se a esta última. $\mathrm{O}$ abandono em que jazeram teve função benéfica. Libertou-os da adaptação penosíssima a um estado social superior e, simultaneamente, evitou que descambassem para as aberrações e vícios dos meios adiantados" (CUNHA, 1957, p.99).
\end{abstract}

Os cinco mil sertanejos comandados por Antônio Conselheiro (segundo os escritos do pesquisador, que foram visivelmente baseados no evolucionismo spenceriano) tinham estrutura uniforme e eram moldados naturalmente pelo meio em que viviam. Ganhavam força com a rusticidade da terra, das plantas e dos animais que os acobertavam, assim como pareciam retirar energia adormecida de um corpo moldado por uma amálgama de qualidades importantes, como a resistência indígena aliada à inteligência e à determinação dos exploradores bandeirantes: 
O homem do sertão parece feito por um molde único, revelando quase os mesmos caracteres físicos, a mesma tez, variando brevemente do mameluco bronzeado ao cafuzo trigueiro; cabelo corredio e duro ou levemente ondeado; a mesma envergadura atlética, e os mesmo caracteres morais traduzindo-se nas mesmas superstições, nos mesmos vícios, e nas mesmas virtudes. A uniformidade, sob estes vários aspectos, é impressionadora. O sertanejo do norte é, inegavelmente, o tipo de uma subcategoria étnica já constituída. (CUNHA, 1957, p.96)

Aliado ao corpo rústico, a mente tida por Cunha como primitiva também fortalecia a luta e revelava o misticismo que unia homem e natureza. Como analisa Rezende (2001), Cunha apontava aspectos visivelmente positivos na cultura do sertanejo:

A sua brabeza persistente, a sua determinação em arrancar os meios de sobrevivência em condições inóspitas e a sua honestidade para com os outros eram pontos indicativos de que o Brasil possuía, em seus lugares mais obscuros e desconhecidos, seres sociais dotados de características que se faziam necessárias para implementar qualquer processo de mudança no Brasil" (REZENDE, 2001, p.213).

Alguns autores chegaram a aclamar no final do século XIX a maneira como o país seguia sua formação política e social. Também explicitamente influenciado pelo evolucionismo de Spencer, Silvio Romero chegou a colocar o mestiçamento como uma das pilastras da futura democracia, adiantando em muitos séculos a busca pela igualdade entre os homens. Neste parágrafo, extraído de "A mudança social em Silvio Romero" (apud REZENDE, 2001), tal análise é ratificada:

O Brasil é um país fatalmente democrático. Filho da cultura moderna, nascido na época das grandes navegações e das grandes descobertas, o que importa dizer, depois da constituição forte da plebe e da burguesia, ele é, além do mais, o resultado do cruzamento das raças diversas, onde evidentemente predomina o sangue tropical. Ora, os dois maiores 
fatores de igualização entre os homens são a democracia e o mestiçamento. E estas condições não nos faltam em grau algum, temo-las de sobra" .

Mas com o passar do tempo, percebe-se que a resistência do "corpo rústico" não seria suficiente para suportar as pressões impostas pela Monarquia e, futuramente, pelo Estado Republicano. Observando as mobilizações populares ocorridas no interior do Brasil - seja por parte dos sertanejos de Canudos no século XIX, seja pelas Ligas Camponesas no século XX, seja pelos sem-terra no século XXI - percebemos que os conflitos estão impregnados de misticismo (em maior ou menor escala) e de ações e reações ferrenhas que acabariam evoluindo cada vez mais dentro do campo político e menos no ambiente das guerrilhas genocidas (discutiremos isso mais adiante).

As contradições registradas entre os religiosos interioranos (que defendiam as minorias e eram simpatizantes de Antonio Conselheiro) e o clero urbano - até então monárquico e que rapidamente passara a ratificar as ações republicanas - são repetidas em outros fatos pontuais da história. Movimentos sociais modernos do campo sempre receberam apoio de setores libertários das igrejas. Assim como o Estado reprimiu as tentativas de criar redutos jesuítas no Sul da América Latina ("recatequizando" os índios e tentando darlhes uma "vida intermediária" entre obrigações cotidianas e a liberdade aparentemente enraizada nas Missões), Conselheiro também teve seus projetos frustrados pelo medo da "elite letrada", que via nascer uma suposta sociedade livre das mãos pesadas da República, sem leis e sem controle da distribuição de terra e renda. Nos dois exemplos citados, a repressão foi feroz e teve o apoio de correntes conservadoras da mesma Igreja.

Logo nas primeiras páginas de A Sociologia no Brasil, Florestan Fernandes destaca que, no início do século XIX, “a Igreja fazia parte e era solidária, material e moralmente, dos empreendimentos colonizadores do Reino" (FERNANDES, 1977, p.17). Tal intimidade legitimava repressões armadas e angariava apoio das camadas populares urbanas analfabetas, já que as classes superiores 
eram naturalmente favoráveis a qualquer ação da Coroa. A mudança para Estado republicano nada alterou a "solidariedade" entre a cúpula do clero e grupos dominantes.

\section{Ações e reações}

A resistência dos camponeses de Canudos forneceu bons fluidos à chama de um ideal (a busca por um lar aos seus descendentes) mas não garantiu solidez ao processo de democratização da terra, podado antes mesmo da metade do século XIX. A história relata (e confirma) as intenções da Coroa - seguidas pela República - em garantir a preservação dos interesses dominantes.

Se a colonização do interior foi importante para estender e concretizar as fronteiras nacionais, a imposição dos costumes europeus e a continuidade do pensamento feudal ${ }^{4}$ - seguidas pela visão extrativista, escravocrata e de classes sociais rigidamente distantes entre si - adoeceram a sociedade brasileira já no seu período de gestação.

Joaquim Nabuco, por exemplo, já defendia em 1884 (durante comícios e discursos em campanhas eleitorais de Recife), mudanças na

4 Não nos referimos aqui ao Brasil pré-colonial como detentor de resquícios feudais no âmbito econômico, mas sim à condição social do país dominada pela repressão e estagnação quase medievais, tal qual observa GUIMARÃES (1968). Para o autor, os senhores das terras (assim como os senhores feudais) "determinam as condições dos contratos de trabalho, as formas de remuneração, os tipos de arrendamento, as lavouras e criações permitidas, os preços dos produtos, os horários de trabalbo, os serviços gratuitos a prestar, ditam as sentenças judiciais e impõem as restrições à liberdade que thes convêm, sem o mínimo respeito às leis vigentes" (1968, p. 36). De qualquer modo, evitamos afirmar que o período pós-descobrimento tenha-se amparado na estrutura feudal européia. Entre outros fatores, lembramos que os acordos entre o detentor das terras (a Coroa portuguesa) e os usuários das mesmas (donatários) não se caracterizavam como a relação entre suserano e vassalo, mas sim no âmbito das relações entre rei súditos. "Não havia no sistema brasileiro nem o feudo nem o vínculo de vassalagem, triturados ambos pela economia mercantil", afirma FAORO (1989, p. 13), levantando outra questão divergente entre autores brasileiros sobre a existência ou não de raízes feudais na colonização brasileira: o caráter comercial da produção na época tinha características capitalistas ou mercantilistas? Além de Faoro e Guimarães, reforçamos a sugestão de leitura dos autores citados na nota n.2. 
lei agrária, uma distribuição igualitária de terras e (como principal representante do abolicionismo que era), oportunidade para o negro encontrar seu espaço para plantar e viver em paz:

A propriedade não tem somente direitos, tem também deveres, e o estado da pobreza entre nós, a indiferença com que todos olham para a condição do povo, não faz honra à propriedade, como não faz honra ao Estado. Eu, pois se for eleito, não separarei mais as duas questões - a da emancipação dos escravos e a da democratização do solo. Uma é o complemento da outra. Acabar com a escravidão não nos basta; é preciso destruir a obra da escravidão. (...) Sei que falando assim, serei acusado de ser um nivelador. Mas não tenho medo de qualificativos. Sim, eu quisera nivelar a sociedade, mas para cima, fazendo-se chegar ao nível do art. 179 da Constituição do Império que nos declara todos iguais perante a lei (NABUCO, 1988, p. 42).

Nabuco também fazia reflexões sobre o resultado da exploração colonialista, seja do solo ou dos escravos, e rechaçava a falsa idéia de apropriação legal da terra, anteriormente usurpada dos índios:

[...]A obra de uma escravidão: onde ela chega queima as florestas, minera e esgota o solo, e quando levanta as suas tendas deixa após si um país devastado em que consegue vegetar uma população miserável de proletários nômades. [...] A população não possui definitivamente o solo: o grande proprietário conquistou-o à natureza com os seus escravos, explorou-o, enriqueceu por ele extenuando-o, depois falou pelo emprego extravagante que tem quase sempre a fortuna mal adquirida, e, por fim, esse solo voltou à natureza, estragado e exausto (NABUCO, 2000, p.105-106).

Apesar da luta e dos questionamentos de tantos pensadores - dentro e fora do âmbito político - e das mobilizações iniciadas pelas Santidades indígenas, é possível perceber como tais ações foram e são automaticamente sucedidas por reações. São contraataques amparados por instituições que garantiram e garantem continuidade ao sistema de dominação agrária existente no país. A prin- 
cipal barreira erguida no século XIX contra as minorias sem direito à propriedade foi a Lei das Terras de 1850 , que "extinguia o princípio da doação e inaugurava o da compra, para aquisição de terras devolutas [...]. Tratava-se de dificultar o acesso à terra, por parte de ex-escravos, camaradas, imigrantes, colonos, moradores e outros" (IANNI, 1984, p.175).

Mesmo não possuindo um caráter necessariamente de movimento camponês criado para lutar pela distribuição de terras, o messianismo de Canudos - além de combatido e dizimado - ainda foi sucedido pela criação da Sociedade Nacional da Agricultura (1897), órgão que intimidaria qualquer projeto futuro que pretendesse disseminar pequenas propriedades rurais no Brasil (principalmente por meio de pressões políticas, já que a bancada de deputados ruralistas passou a ganhar um importante aliado formal quando questões agrárias tramitavam no Congresso). Outro exemplo que pode ser citado é a Guerra do Contestado, considerada por José de Souza Martins (1986) "a maior guerra popular da história contemporânea do Brasil".

Ocorrida na divisa do Paraná com Santa Catarina entre 1912 e 1916, o confronto registrou 20 mil rebeldes e também metade do Exército Brasileiro, além de uma tropa de quase mil combatentes civis convocados pelas Forças Armadas (os chamados "vaqueanos"). O saldo de três mil mortos forçou um debate nacional nos anos seguintes e, entre outras ações repressivas dos grupos dominantes, influenciou a criação da Sociedade Rural Brasileira em 1919, outra organização onde prevaleciam os desejos dos grandes agropecuaristas.

Saltando mais à frente na história da sociedade brasileira e suas mobilizações, basta resgatar o período de ebulição dos movimentos populares rurais a partir da década de 50 . O campesinato passa a perceber que ações conjuntas poderiam transformar as condições socioeconômicas do interior. Foi o período das Ligas Camponesas, da ULTAB (União dos Lavradores e Trabalhadores Agrícolas do Brasil), do MASTER (Movimento dos Agricultores Sem Terra do Rio Grande do Sul), dos sindicatos rurais e também das guerrilhas espalhadas pelo interior do Brasil. Uma década de agitação política e social não poderia deixar de preocupar os grupos dominantes e conservadores do meio agrário. 
A gota d'água para os fazendeiros foi a SUPRA (Superintendência da Reforma Agrária), criada por João Goulart em 1962, que desencadeou (juntamente com outros fatores) o golpe militar de 1964. É verdade que o governo Castelo Branco apresentou o Estatuto da Terra, considerado "avançado" para a época. "Este, somado ao Estatuto do Trabalhador Rural, já aprovado anteriormente, poderiam se constituir em instrumentos legais para a promoção da reforma agrária" (OLIVEIRA, 1999, p.28). Mas o processo de distribuição de terra deveria seguir os moldes herméticos militares: "promover a reforma agrária dentro da justiça social sem o toque vermelho dos partidos comunistas". O Estatuto, que nunca chegou a ser aproveitado integralmente na prática e ainda prejudicou pequenos e médios produtores rurais ${ }^{5}$, teve parte do seu texto usada como referência para o Primeiro Plano Nacional de Reforma Agrária - PNRA - desenvolvido pelo presidente José Sarney 20 anos depois. A represália ao PNRA também foi forte em 1985. A criação da União Democrática Ruralista (UDR), no mesmo ano, expressou o combate às metas do plano $\mathrm{e}$ também a um jovem grupo de ativistas nascido oficialmente no ano anterior: o Movimento dos Trabalhadores Rurais Sem Terra (MST).

Certamente a repressão que marcou a década de 60 não foi provocada única e exclusivamente pelas agitações do campo.

O quadro político nacional e internacional apontava "novos problemas" a serem enfrentados pelos homens do poder. Um bom exem-

5 O Estatuto da Terra apresentou "novidades" dentro do setor agrário brasileiro, como a designação de nomes para propriedade com até 15 hectares (de minifúndio passou para módulo rural), e para áreas que superassem 600 vezes este índice (com mais de $50 \%$ da área agricultável era chamada de empresa rural, similar à farmer norte-americana). Caso fosse improdutiva, ganharia o nome de latifúndio por exploração. O problema foi que tais nomenclaturas engessaram os limites das propriedades, prejudicando os pequenos e médios agricultores. Além disso, diversos grupos empresariais e multinacionais (amparados pelo Estatuto) conseguiram direito de uso em extensas áreas do Norte brasileiro (por conter rico material visual, sugerimos leitura da Revista Realidade Especial - Editora Abril, nº 67 , outubro de 1971 - que fala sobre a ocupação da Amazônia). Vale ressaltar que uma inovação foi a definição da "função social da terra" e também a criação do Imposto Territorial Rural (ITR). "Até então os grandes proprietário brasileiros jamais haviam pago um centavo sequer de tributo sobre a propriedade" (MORISSAWA, 2001, p.99-100). 
plo foram as mentes "anticomunistas" que ficaram fervilhantes com a tomada da capital Havana em Cuba (iniciada dia 2 de janeiro de 1959 pelo Exército revolucionário). Grupos formados por intelectuais, estudantes, operários e até mesmo por lideranças religiosas gritavam aos quatro ventos a "nova sociedade" que apontava no horizonte brasileiro (o próprio presidente Jânio Quadros, acompanhado de duas lideranças das Ligas Camponesas, visitou Havana em abril de 1960).

Mas ainda assim nem todos os movimentos sociais eram ou são de conteúdo progressista e transformador. As influências podem vir das mais diversas alas dentro de um quadro político complexo como o existente no Brasil. É preciso ressaltar o quanto é comum perceber feições reformistas ou conservadoras que um determinado movimento pode assumir. Isso porque há ascendências diversas, internas e externas, transitando nas discussões dos grupos.

Entre a diversidade de influências aparentemente antagônicas dentro dos conflitos modernos podemos resgatar as Ligas Camponesas (inspiradas nos revolucionários latino-americanos), o associativismo da ULTAB (braço rural do Partido Comunista e com tendências mais brandas que as das Ligas) e a Igreja Católica, que enraizou influências conservadoras por meio de sua doutrina social cristã. Esta última, idealizada inicialmente para orientar os camponeses a buscarem, compromissados com a não-violência, seus direitos por meio da discussão com as lideranças governamentais, acabou desembocando, duas décadas depois, em uma nova diretiva impregnada na maioria dos movimentos sociais da atualidade: a Teologia da Libertação. No campo, ela fortaleceu e deu estrutura aos primeiros passos da Comissão da Pastoral da Terra (CPT).

Vale destacar que estamos nominando entidades (ULTAB, Ligas, etc.) para compor uma linha de influências na tentativa de oferecer um "mapa" temporal e histórico moderno das lutas no campo, mas sem esquecer as raízes longínquas. Caldart (2000) também cita as entidades por nós destacadas, mas desenvolve seus estudos sobre os primórdios do Movimento dos Sem-Terra, sintetizando as influências clássicas como "matrizes culturais". As matrizes camponesas e religiosas, segundo a autora, constituem basicamente a tradição conservadora do movimento. Esta tradição, no entanto, sempre recebeu influências dos 
processos revolucionários ocorridos no campo, reforçada pela repressão marcante das autoridades:

\begin{abstract}
A raiz camponesa do MST tem a ver especialmente com a dimensão dos lutadores sociais do campo, misturando na herança pessoal da maioria dos seus integrantes os traços do que podemos chamar do modo cotidiano de vida camponesa, com elementos fortes da tradição de conservação e, ao mesmo tempo, de rebeldia social. Isto quer dizer que na formação dos sem terra há um processo de tensionamento cultural que implica em uma reapropriação e, ao mesmo tempo em uma recriação da sua própria raiz. (...) Há uma recuperação e uma recriação de sentido nestes nexos que se estabelecem entre cultura camponesa, cultura religiosa e cultura de lutas sociais (CALDART, 2000, p.33)
\end{abstract}

A idéia de que a luta pela reforma agrária se faz no campo mas se decide na cidade já foi assimilada pelos movimentos sociais modernos rurais há alguns anos, o que transformou definitivamente a imagem que os integrantes tinham sobre as lutas de classes. Percebeu-se que, antes de projetar ideologias, era preciso definir escolhas "morais". Não estamos falando aqui de conceitos que embandeiram entidades como a TFP - Tradição, Família e Propriedade: grupo criado no Brasil em 1960 e que centralizou suas ações contra o "comunismo inspirador das ações no campo" (OLIVEIRA, 1980). Os valores morais a que estamos nos referindo estão ligados à união familiar, à preocupação com o coletivo e à participação política de todo cidadão diante das injustiças visíveis de uma sociedade desigual. Situações percebidas desde os tempos dos seguidores de Antonio Conselheiro. Thompson afirma que "toda luta de classes é aó mesmo tempo uma luta acerca de valores, e o projeto do socialismo não está garantido por nada e pode encontrar suas próprias garantias somente pela razão e por meio de uma ampla escolha de valores" (THOMPSON, 1981, p.190).

E para compreender a escolha de valores da classe proletária, Thompson buscou conhecer os fatos históricos pela perspectiva dos operários britânicos (vide os três volumes de "A formação da classe operária inglesa"). Assim como Thompson (1987) e Eric Hobsbawm (1988) também buscaram ver a história "de cabeça para baixo", a partir 
dos movimentos populares e das pessoas comuns que os compunham.

Autores brasileiros também colocaram os heróis anônimos no topo da história para compreender a evolução da sociedade local. Desde narrativas "in loco" ("Os Sertões", de Euclides da Cunha), passando por pesquisas históricas ("América Latina: Males de Origem", Manoel Bonfim) e análises das mudanças no campo e na cidade dos séculos que antecederam a virada do milênio (Gilberto Freyre, em "Casa Grande \& Senzala" e "Sobrados e Mocambos"), entre tantos outros. Aquino (2000) também deu espaço aos personagens sem nome que fizeram a história do Brasil.

Bomfim (1993, p.188) fala de maneira apaixonante sobre o caminho que cada indivíduo deve trilhar para alcançar uma sociedade verdadeiramente livre e igualitária, onde "ser livre é ser capaz de encontrar um sentido social para a vida. Os indivíduos só encontram de fato, a autonomia, quando fundam as atividades na construção de uma vida social para todos".

\section{Formação e informação}

Mas para concretizar a liberdade almejada por pensadores e cidadãos comuns, choques entre ideais nacionalistas e teses formuladas na Europa colocavam homens "letrados" em uma encruzilhada histórico-sociológica desde o século XIX. Mesmo tentando burilar uma sociologia verdadeiramente brasileira, muitos eram flagrados em uma dependência de teorias diversas (spencerianas, lamarckianas, contistas, entre outras), inconscientemente impregnadas e ancoradas em uma formação educacional forjada em escolas francesas e inglesas. Joaquim Nabuco, por exemplo, advogava pelo fim da escravidão; sugeria, no entanto, que as mudanças sociais jamais partissem dos quilombos, mas sim do parlamento, reforçando a idéia moderna do MST que a "luta se faz no campo, mas se decide na cidade".

Silvio Romero, mesmo que simpatizante de uma nação "adiantada socialmente" em relação aos países europeus graças à miscigenação das raças, temia a industrialização do Brasil (possível gênesis de 
um proletariado urbano desorganizado e prejudicial à sociedade em evolução). O pensador sugeria a manutenção de um Brasil agrário nos moldes vigentes da época (latifúndios que barravam a criação de pequenas propriedades e a presença de proprietários negros, colonos e imigrantes).

Euclides da Cunha, ainda que estupendo em sua análise diante de tamanho genocídio presenciado em Canudos, acreditava que a evolução da sociedade brasileira poderia ser melhorada com o cruzamento do índio com o branco, mas seria prejudicada pela união exacerbada entre brancos e negros ou índios e negros: "Ante as conclusões do evolucionismo, ainda quando reaja sobre o produto o influxo de uma raça superior, despontam vivíssimos estigmas da inferior. A mestiçagem extremada é um retrocesso. (CUNHA, 1957, p.96)

Tais conflitos - encontrados em análises de muitos intelectuais entre os séculos XIX e XX - têm com uma das possíveis origens a formação acadêmica conflitante dos herdeiros de homens que integravam a cúpula dominante. Enquanto a elite enviava seus descendentes para garantir formação no exterior, outras classes abastadas "genuinamente" brasileiras (a maioria dos integrantes da elite tinha raízes monárquicas portuguesas) também buscavam fazer de seus filhos homens letrados nos grandes centros (São Paulo e Rio de Janeiro). Era a aristocracia rural perpetuando o engessado monopólio político, social e econômico. Com tal aprendizagem, seja no exterior seja no Sudeste do País, acumulavam-se idéias inovadoras muitas vezes truncadas. Bomfim (1993) apontava a inoperância burguesa contraposta aos trabalhos braçais e o medo de labutar como péssimos referenciais herdados pela sociedade moderna brasileira:

Só o escravo trabalhava, só ele era produtivo. Nenhum braço português tocava os engenhos nas roças de São Tomé ou do Brasil. E com isso resultou que o trabalho foi considerado, cada vez mais, como coisa vil, infamante. $O$ ideal de todos era viver sem nada fazer - ter escravos e à custa deles passar a vida $\mathrm{e}$ enriquecer. Este ideal aí persiste como tradição. Ainda hoje, mesmo os homens que conseguiram pelo seu labor próprio e esforço pessoal uma situação social desafogada e próspera, só aspiram para os filhos às profissões em que lhes parece que não será preciso trabalhar (BOMFIM, 1993, p.132). 
Nabuco vai além e faz uma conexão entre a vida regada da burguesia com o seqüestro e mau uso das riquezas do campo. Mas para os senhorios agrários, o autor apontou a inevitável queda vertiginosa da qualidade de vida dos descendentes como herança e (ao mesmo tempo) condenação :

A aristocracia que possui a terra não se entrega a ela, não trata de torná-la a morada permanente, saudável, e cheia de conforto de uma população feliz; as famílias são todas nômades enquanto gravitam para o mesmo centro, que é a Corte. A fazenda ou o engenho serve para cavar o dinheiro que se vai gastar na cidade, para a hibernação, e o aborrecimento de uma parte do ano. A terra não é fertilizada pelas economias do pobre, nem pela generosidade do rico; a pequena propriedade não existe senão por tolerância, não há as classes médias que fazem a força das nações. Há o opulento senhor de escravos e proletários. A nação, de fato, é formada de proletários, porque os descendentes dos senhores logo chegam a sê-lo (NABUCO, 2000, p.111).

São reflexões como a destes pensadores que representavam, na visão de Fernandes (1977), o amadurecimento de algumas facções da sociedade brasileira. No entanto, a burguesia começou a "pensar e trabalhar" mais por pressão da complexidade crescente da máquina estatal que pelo desejo de mudanças sociais profundas:

As condições sociais e culturais, que servem de suporte e oferecem meios favoráveis de desenvolvimento ao saber racional, começam a constituir-se com ritmo regular, na sociedade brasileira, a partir do primeiro decênio do século XIX. Nessa época surgem as primeiras pressões no sentido de adestrar um setor maior da população para o exercício de tarefas administrativas e políticas ou para enfrentar necessidades que emergem com a expansão econômica e com o crescimento demográfico (FERNANDES, 1977, p.17).

Com tantos entraves brotando aos pés de uma transição entre Monarquia e Estado republicano, como garantir o direito às manifestações, mobilizações populares ou conquistas de direitos sociais bá- 
sicos, se os primeiros homens libertários estavam "presos" a teorias e métodos estrangeiros que delimitavam o avanço de um pensamento sociológico?

Se tais pressupostos deturpavam as visões (ou previsões) dos "homens de saber", imaginem como eram vistas as iniciativas do povo interiorano pelos anônimos homens urbanos, fossem eles integrantes ou não da elite descendente de um "Estado colonizador". Cunha percebeu a "onda" negativa que afogava a sociedade litorânea da época, diante de informações deturpadas do grupo rebelde instalado em Canudos absorvidas pela população urbana:

\begin{abstract}
Viu-se, então, um caso vulgaríssimo de psicologia coletiva: colhida de surpresa, a maioria do país inerte e absolutamente neutral, constituiu-se veículo propício à transmissão de todos os elementos condenáveis que cada cidadão, isoladamente, deplorava. Segundo o processo instintivo, que lembra na esfera social a herança de remotíssima predisposição biológica, tão bem expressa no mimetismo psíquico de que nos fala Scipio Sighele ${ }^{6}$, as maiorias conscientes, mas tímidas, revestiam-se, em parte, da mesma feição moral dos medíocres atrevidos que lhes tomavam a frente (CUNHA, 1957, p.259).
\end{abstract}

Tais problemas de interpretação são identificados na história recente, ainda mais com o poder da mídia moderna. É importante lembrar que Cunha integrava a $4^{\mathrm{a}}$ Comitiva do Exército republicano como correspondente do jornal "A Província de São Paulo" (atual "O Estado de São Paulo") e, mesmo criticando a "psicologia coletiva" presenciada nos grandes centros, ele próprio fortaleceu o imaginário popular com visões certas vezes preconceituosas e unilaterais sobre o sertanejo e sobre a guerra. Em artigo publicado recentemente, o sociólogo Sérgio Paulo Rouanet ressalta certas equivalências entre os opostos. Similaridades também percebidas por Euclides da Cunha ao final d' Os Sertões:

${ }^{6} \mathrm{O}$ positivista Sighele - juntamente com Le Bom - defendia a tese da psicologia coletiva, quando se referia a ações coletivas e à "turba" (mobilização unida por um pensamento comum. 
As forças que representavam a modernidade eram elas próprias arcaicas. O delírio de Canudos tinha uma contrapartida exata na capital. Em Canudos, os jagunços baleavam os intrusos com seus clavinotes; no Rio, os florianistas linchavam transeuntes e empastelavam jornais. Para os conselheiristas, a república era o reino do anticristo; para os citadinos, Canudos era o centro de uma conspiração monarquista. Para os cariocas, Canudos era a Vendéia; para os jagunços, o Rio era a Babilônia. Os conselheiristas tocavam sinos e cantavam hinos religiosos. As tropas do governo saudavam o aniversário da queda da Bastilha metralhando os jagunços com salvas de 21 tiros e cantando o Hino Nacional. Os dois campos se interpenetravam" (ROUANET, 2002, p.12).

O sociológo reforça ainda, juntamente com Cunha, que o fanatismo registrado durante a guerra de Canudos era curiosamente semelhante e ao mesmo tempo ambivalente:

A crueldade era idêntica nos dois lados. Para Euclides, o Conselheiro e o coronel Moreira César eram figuras simétricas. O Conselheiro era um doente mental; o coronel, um epilético. Duas patologias, reforçadas por duas sociedades retrógradas. $\mathrm{O}$ uniforme de Moreira era o avesso do camisolão azul de Conselheiro" (ROUANET, 2002, p.12)

A diferença primordial entre "florianistas" e "conselheiristas" seria a cultura dos sertanejos embasada em uma formação sociocultural "limitada" e demarcada ainda mais pela geografia de sua terra (referimo-nos ao sertão, que mesmo rude, forjou seu residente e deu-lhe proteção durante a guerra). Rezende (2001, p.212) destaca que, para Euclides da Cunha, "se eles faziam [mobilizações] de um jeito permeado por ignorâncias e fanatismos é porque eles não conheciam nenhuma outra maneira", diferentemente dos comandantes da expedição e principalmente das "cabeças pensantes" urbanas que poderiam, pelo menos, reivindicar medidas mais humanas na solução de tal impasse.

Passados cem anos, tal situação nunca foi tão atual dentro das discussões sobre as ações de movimentos populares rurais modernos. Ouvimos os mesmos argumentos (seja da voz do povo seja de analis- 
tas que consideram "retrógrada e ignorante" a maneira como as mobilizações camponesas estão buscando a reforma agrária) e percebemos as mesmas referências reproduzidas na mídia, tal qual se sucedeu - por exemplo - durante a mobilização de Canudos.

\section{As mobilizações delirantes das mídias}

Já que o artigo resgata mobilizações sociais históricas do Brasil, este texto não poderia deixar de inserir alguns parágrafos sobre a imagem dos movimentos sociais apresentada pela opinião pública à população. Mesmo porque uma recente reportagem publicada pela revista de maior circulação nacional reforça diretamente as colocações apresentadas nas páginas anteriores. A edição n 1807 da Veja (SALGADO; PERES, 2003) exibe na capa uma foto na qual José Rainha, uma das principais lideranças dos sem-terra, aparece como idealizador do que seria a "Nova Canudos", ou o maior acampamento já organizado no Brasil. Sob o título "A Esquerda Delirante", o texto de apresentação deixa claro o objetivo do semanário: mostrar os ideais do movimento como extremistas e fanáticos:

Com raras exceções, Canudos aparece na débil historiografia brasileira como a mais bem sucedida experiência de organização popular da história do país, um movimento que soube canalizar as insatisfações do campo para produzir uma explosão social revolucionária. Como quase todo militante de seu credo, Rainha acredita na glorificação ideológica do que foi apenas uma insurreição de fanáticos, hipnotizados por um líder carismático, o beato Antônio Conselheiro (SALGADO; PERES, 2003, p.74).

A revista Época é outro exemplo, que apresentou na capa o título "Reforma Agrária: a classe média do campo" (ADEODATO et al., 2000), (alusão direta a dados apurados pelo INCRA, onde assentados em terras disponibilizadas pela Reforma Agrária teriam renda mensal média superior à dos agricultores brasileiros), foram substituídas três anos depois (edição ${ }^{\circ} 268$, julho de 2003) pelo teor crítico que embasou outra manchete de capa "MST: eles querem a revolução" (CAMAROTTI, 
2003) (falando sobre as jovens lideranças que estariam fortemente inspiradas na experiências soviéticas e cubanas).

Mesmo desenvolvendo projetos de formação técnica e educacional, criando cooperativas e usando a "luta pela redistribuição de terras" como principal bandeira para um provável reequilíbrio de uma sociedade, o MST passou a ser alvo de reportagens, pesquisas, histórias e exageros, tais quais a visão disseminada pela sociedade brasileira do final do século XIX. Não convém julgar neste parágrafo os erros (foram muitos, por sinal) e acertos dos sem-terra, mas sim ressaltar a maneira como o grupo é apresentado na mídia, na qual muitas vezes aparece deslocado de um contexto histórico, sociológico e até mesmo legal). Ghon (2000) cita como exemplo a grande marcha de 1997, quando milhares de sem-terra e integrantes de entidades, partidos políticos de esquerda, ONGs e outros movimentos populares, ocuparam a Esplanada dos Ministérios em Brasília, resultando em manchetes como "A marcha dos radicais" e "Governo Sitiado" mesmo diante de uma pesquisa do Ibope (realizada entre 6 e 10 março de 1997), a qual apurava que $94 \%$ dos entrevistados apoiavam a luta pela reforma agrária mantida pelo $\mathrm{MST}^{9}$.

Assim como os sertanejos de Canudos, as principais referências dos sem-terra - pessoas fortemente ligadas à religião e detentoras da vontade guerreira dos grandes revolucionários - aparecem na mídia com tintas carregadas, esboçando imagens de messiânicos e idealistas retrógrados de inspiração comunista. É verdade (como apresentamos anteriormente) que este movimento em específico apresenta comportamentos curiosamente conservadores sob vestes rebeldes, mas a maneira como a imagem do MST é projetada pelos veículos de comunicação deixa emergir mais uma vez que o sistema "ação"

${ }^{7}$ Veja, 16 abr. 1997

s Isto É, 23 abr. 1997.

9 Vale ressaltar que prêmios internacionais (como a condecoração Rei Balduíno, na Bélgica), apoio de grandes representantes culturais (como a parceria do cantor e compositor Chico Buarque com o escritor português José Saramago e o fotógrafo Sebastião Salgado no Livro "Terra", totalmente dedicado ao MST) e até mesmo de programas populares televisivos (em 97, a novela Rei do Gado (TV Globo) apresentava "personagens e mensagens positivas" ligadas aos semterra) reforçaram os índices de aprovação do movimento naquele ano. 
(das camadas populares) e "reação" (dos grupos dominantes) encontrado em diversos períodos da história brasileira continua sendo perpetuado depois da virada do milênio por meio de processos midiáticos cada vez mais modernos.

$\mathrm{E}$ é esta modernidade que parece ser o enfrentamento maior a ser iniciado pelos movimentos sociais. É compreensível, por exemplo, que a formação basicamente religiosa - alinhavada pela Teologia da Libertação - dificulte dirigentes, professores e pais sem terra a oferecerem uma imagem ampliada aos filhos do que seria o ideal do grupo como o principal representante das mobilizações populares da atualidade dentro dos espaços públicos que vêm se ampliando a cada ano, visto que os mais velhos têm dificuldade em discutir com a juventude temas complexos atuais, ligados ou não diretamente aos movimentos sociais (desemprego, homossexualismo, ecologia, genética, entre outros assuntos):

O MST tem propostas modernas para as questões econômicas (como as cooperativas), mas ainda tem dificuldades em algumas questões-chave da era da modernidade, como a dos direitos nas problemáticas de gênero (em especial, sobre as mulheres), em questões culturais sobre raças e etnias (especialmente sobre a população negra, pobre ou a população indígena)" (GHON, 2000, p.154).

${ }^{10}$ Como já existe uma vasta literatura para os exemplos citados, aqui vão sugestões de produções cinematográficas para assimilar tais temas: "Guerra dos Pelados" (1971), dirigido por Sylvio Back; "Guerra de Canudos" (1997), de Sérgio Rezende; "Quilombo" (1984), de Carlos Diegues; "Os Mucker" (1978), dos diretores Jorge Bodansky e Wolf Gauer; e "A Paixão de Jacobina" (2002), de Fábio Barreto. Os dois últimos estão ligados ao movimento messiânico ocorrido nas colônias alemãs de São Leopoldo e Sapiranga (RS), entre 1873 e 1874. Liderados por Johann Georg Mauer (curandeiro conhecido como João Jorge) e sua esposa Jacobina Mentz Maurer, os Mucker foram dizimados pelas milícias da província depois de terem sido acusados - por padres católicos e pastores protestantes - de formarem seitas dentro da comunidade). Referências sobre outras revoltas, rebeliões, guerras internas e repressões governistas podem ser encontradas em diversos livros. Destaque para todos os volumes clássicos da História Geral da Civilização Brasileira, de Sérgio Buarque de Holanda (São Paulo : DIFEL, 1962, 1964, 1974 e 1985) Entre as obras recentes, destaque para Sociedade Brasileira: uma história através dos movimentos sociais de Aquino et al. (2000), utilizado várias vezes neste trabalho e onde são visualizadas as principais mobilizações populares do Brasil. 
Não é intenção deste artigo perpetuar o negativismo perene das classes dominantes, relacionado pejorativamente a influências religiosas e mobilizações populares. Nem é preciso relembrar da importância das crenças no dinamismo de certas ações populares: estão presentes nas Santidades, nos quilombos, nas guerras do Contestado e de Canudos ou na Revolta dos Mucker ${ }^{10}$, entre outros. Fanatismo? Delírios messiâ-nicos? Conservadorismo? Todas estas afirmações estão entre os adjetivos de vários levantes históricos brasileiros, mas a função da religião como importante engrenagem e "estopim" de reações antigovernistas e anticapitalistas merece ser destacada.

\section{Considerações finais}

Percebendo as influências históricas dos movimentos sociais do campo no Brasil (descritas resumidamente neste trabalho), é possível traçar uma identidade costurada com retalhos conflitantes, com influências e ideologias embebidas de conservadorismo e rebeldia (acampamentos do MST e a aldeia de Canudos transpiravam o mesmo paradoxo). A própria definição de "resistência" entre eles é transpassada por vertentes revolucionarias e provações de fé.

No sismógrafo da história, as mudanças de atitudes eram (e são) rápidas e pulsantes, alternando lutas armadas com mobilizações pacíficas no campo e na cidade. Vemos pensamentos díspares, que vão da consciência política reforçada por lideranças urbanas até a simples "teimosia" dos agricultores - analfabetos e pioneiros - em fincar os pés na terra onde sua família viveu gerações. A mesma insistência exposta no ideal apontado por Thompson (1987), que preenche a memória dos expropriados desde seus ancestrais. "A vida na terra, para eles, é um modo de vida do qual famílias inteiras são expropriadas. O ideal de voltar (a terra) pode persistir por uma, duas, três gerações", reforçam Bergamasco, Ferrante e D'Aquino (1990, p.272).

Em meio a tantas incertezas sobre o futuro no campo, a luta pela reforma agrária parece continuar, pela inserção do assunto seja nos espaços públicos arendtianos, seja na pauta dos debates acadêmicos, seja na mídia, seja nas discussões dos legislativos estaduais e Federal. 
No centenário da destruição de Canudos, o pesquisador Hoornaert (1997) sugeriu que as respostas para os questionamentos deixados pelos sertanejos do passado ainda estão pairando no ar e ajudando a formar aos poucos não somente o camponês que integra os movimentos rurais modernos, mas cada indivíduo genuinamente brasileiro, seja ele índio, negro, branco ou a mistura de todos:

Canudos, após cem anos, permanece um desafio ainda não solucionado. Aponta para uma convivência mais gratificante entre brasileiros, não só - nem principalmente - em termos de bem-estar social, mas sobretudo pela perseverante construção de uma nacionalidade a partir de paradigmas originariamente cristãos: a indignação, a resistência, a solidariedade e a esperança (HOORNAERT, 1997, p.11).

"Conservar é obra dos mortos. Viver é acrescentar alguma coisa ao que existe" (Manuel Bonfim - 1905) 


\section{Referências}

ADEODATO, Sérgio et al. A Classe média do Campo. Época, n.105, p.36, maio, 2000.

AQUINO, Rubim Santos Leão de et al. Sociedade Brasileira: uma história através dos movimentos sociais. 3. ed. Rio de Janeiro: Record, 2000.

BOMFIM, Manoel. América Latina, males de origem. Rio de Janeiro: Topbooks, 1993.

BERGAMASCO, Maria Aparecida Pereira; FERRANTE, Vera Lúcia Botta; D'AQUINO, Terezinha. Assentamentos de trabalhadores rurais em São Paulo: a roda-viva de seu passado/presente. São Paulo: Vértice, 1990.

CALDART, Roseli Salete. Pedagogia do Movimento Sem Terra. Petrópolis: Vozes, 2000.

CAMAROTTI, Gerson. MST: Os filhos querem a revolução. Época, n.268, p.34, jul. 2003.

CUNHA, Euclides. Os Sertões. São Paulo: Ed. Francisco Alves, 1957

FAORO, Raymundo. Os donos do poder. Rio de Janeiro: Editora Globo, 1989. v.1.

FERNANDES, Florestan. A Sociologia no Brasil. Petrópolis: Vozes, 1977

Antecedentes indígenas: organização social das tribos tupis. In:

HOLANDA, Sérgio Buarque de (Org.). História Geral da Civilização Brasileira. São Paulo: Difusão Européia do Livro, 1960. v.1.

GOHN, Maria da Glória. Midia, terceiro setor e MST: impactos sobre o futuro das cidades e do campo. Petrópolis: Vozes, 2000.

GUIMARÃES, Alberto Passos. Quatro séculos de latifúndio. Rio de Janeiro: Paz e Terra, 1968.

HILL, Christopher. O mundo virado de ponta-cabeça: idéias radicais durante a Revolução Inglesa de 1640. São Paulo: Companhia das Letras, 1987.

HOORNAERT, Eduardo. O sonho dos espaços sagrados. Especial: Canudos Cem anos. Folha de São Paulo, São Paulo, 1997. Caderno "Mais".

HOBSBAWM, Eric. Mundos do trabalho: novos estudos sobre a história operária. Rio de Janeiro: Paz e Terra, 1988.

IANNI, Octavio. Origens Agrárias do Estado Brasileiro. São Paulo: Brasiliense, 1984. 
MARTINS, José de Souza. Os camponeses e a política no Brasil. Petrópolis: Vozes, 1986.

NABUCO, Joaquim. O Abolicionismo. Rio de Janeiro: Nova Fronteira; 2000. (Coleção Grandes Nomes do Pensamento Brasileiro).

. Campanha abolicionista no Recife - Eleições de 1884. Ed. fac-símile.

Recife: Ed. Massangana, 1988.

OLIVEIRA, Ariovaldo Umbelino. Geografia das lutas no campo, São Paulo:

Editora Contexto, 1999.

OLIVEIRA, Plínio Corrêa de. Meio século de Epopéia Anticomunista. São Paulo: Vera Cruz, 1980. (Coleção Tudo sobre a TFP).

REZENDE, Maria José de. Os sertões e os (des) caminhos da mudança social no Brasil. Tempo Social: Revista de Sociologia USP, São Paulo, v.13, n.2, p.201, nov. 2001

ROMERO, Silvio. Obras filosóficas. Rio de Janeiro: José Olympio, 1943. v.1.

ROUANET, Sergio Paulo. O sertão da dialética negativa. Especial Os Sertões Cem anos". Folha de S. Paulo, São Paulo, 1 dez. 2002. Caderno "Mais".

SALGADO, Eduardo; PERES, Leandra. O Beato Rainha. Veja, São Paulo, edição 1.807 , ano 36, n.24, p.72-80, jun. 2003.

SCHADEN, Egon. Aculturação Indígena: ensaio sobre fatores e tendências da mudança cultural de tribos índias em contato com o mundo dos brancos. São Paulo: USP, 1969.

THOMPSON, Edward. A miséria da teoria ou um planetário de erros. Rio de Janeiro: Zahar, 1981.

A formação da classe operária inglesa. Rio de Janeiro: Paz e Terra, 1987.

VAINFAS, Ronaldo. Idolatrias luso-brasileiras: santidades e milenarismos indígenas. In: Zahar Editor, 1992 


\section{Abstract}

The History of Brazil's Rural Social Movements is made of actions and reactions, organized and instinctive decisions, flux and reflux. This article intends to refer, from colonization to nowadays, some of "historic ways" that have guided the first habitants - indians, blackmen, immigrants or white teasants - to fight against the opression caused by capital, large estates and a State that has always proceeded as a tutor of an antiquated agrarian reality. The rusty gears of this reality have been changed, through the last decades, by the force of popular movements that represant an alternative way to soil distribution.

Key words: rural socials moviments, brazilian rural history, MST (Landless Organized Group of Brazil). 